\title{
Purchasing Power Parity Theory and Applications for Solomon
}

\author{
Islands \\ Muthucattu Thomas Paul ${ }^{1 *}$, James D. Kimata ${ }^{2}$ \& M.G.M. Khan ${ }^{2}$ \\ ${ }^{1}$ Department of Business Studies, PNG University of Technology, Morobe Province, Papua New Guinea \\ ${ }^{2}$ The School of Computing, Information and Mathematical Sciences, The University of South Pacific, \\ Laucala Campus, Private Bag, Suva, Fiji Islands \\ * Muthucattu Thomas Paul, E-mail: tommypaul50@gmail.com
}

Received: September 21, 2017

Accepted: October 1, 2017 Online Published: October 9, 2017

doi:10.22158/jepf.v3n4p507

URL: http://dx.doi.org/10.22158/jepf.v3n4p507

\begin{abstract}
We have tested the purchase power parity hypothesis using the consumer price index of USA and UK against Solomon Islands for the sample monthly period from January 1993 to December 2013. This paper uses cointegration and the error correction as methodologies as the data are found to be non-stationary. The result shows that the changes in Solomon Dollars (SBD) per USD are influenced by the long term trends in the price differential of Solomon Islands and the USA. We further investigate the changes in the price differential between Solomon Islands and the UK and establish that they both have a similar trend. The paper asserts that the inflation differential is in the direction of the appreciation of the $S B D / U S D$ and SBD/UK pound which supports the PPP theory in the long run. The symmetry and proportionality of the strong version of PPP were found to be very significant for Solomon Islands against UK pound sterling only and not against USA Dollars.
\end{abstract}

\section{Keywords}

Purchasing Power Parity, cointegration and error correcting models, inflation, open economy

\section{Introduction}

The Purchasing Power Parity (PPP) theory is an important field of study in International Economics and Finance. It is based on the law of one price. The law states that under the assumption of the absence of transportation costs and trade barriers, the price of a good in two countries should be equal if they are of the same quality and are expressed in terms of the same currency. The theory further states that based from the aforementioned law of one price the exchange rates between any two countries will adjust over time to reflect changes in their respective price level. Empirical economists have been using the PPP theory over a long time as a tool to compare the price differences between two countries.

The objective of the study is to investigate if PPP hypothesis determines the exchange rate between the 
Solomon Islands dollar and the United States dollar, and the British pound. This paper employs the cointegration and error correction methodologies in testing the PPP theory. We also test the causal relation between exchange rates and the prices. This testing through the error-correcting methodology implies whether the exchange rates and prices have common stochastic trends and if so, whether the current changes in one variable adjusts to past trend and in lag level forms of the other variable. The Solomon Islands economy has experienced many real shocks during the sample period of our study which ranges from January 1993 to December 2013.

Testing PPP hypothesis is important firstly is because its theoretical perspective in monetary economics which assumes that there is a long-run relationship between money, price and exchange rate (Frenkel \& Johnson, 1978). Secondly the practical perspective of foreign exchange risk management by various economic agent in taking the long-run or short- run on foreign exchange related assets, taking a long-run is sometimes advised (Paul \& Motlaleng, 2008, 2006).

There are other studies done in the developed and developing countries including other African countries regarding the PPP theory (Paul \& Motlaleng, 2008, 2006) but very little were done in the Pacific Islands Countries (PICs). In PICs the common challenges faced are limited, low frequency and incomplete data. This fact could be blamed for the Islands isolation, scatteredness and very remoteness to their market. Recently Jayaraman and Choong (2014) did a study on validity of the PPP theory in five independent dollarized PCIs namely Fiji, Samoa, Solomon Islands, Tonga and Vanuatu. In their study they found a weak long-run PPP for all the five countries but failed to establish evidence for a strong relationship between exchange rate and price level.

This paper tries to further investigate the long-run PPP theory for Solomon Islands dollar against USA dollar and UK pound. We use the Augmented Dick-Fuller tests (ADF) to test for the unit root and Johansen cointegration test to determine the order of integration. We further adopt Error Correction Estimates (ECE) to examine the speed of adjustment for the short-run and to ascertain the existence of the long run PPP. To test the strength of the causation of the exchange rate and the price differential of local dollar against USA dollar and UK pound, we put restriction on coefficient of Consumer Price Index (CPI) of local and the foreign prices and use the log likelihood test to determine the symmetry of the price differential.

The remaining part of the paper is summarized as follows. Section 2 discusses the literature on purchasing power parity theory, exchange rate policy and price for Solomon Islands. In section 3 we give models, variables and sample period and data sources employed in the study. Section 4 presents the empirical results and discussions, while section 5 gives conclusions of our study.

\section{Purchasing Power Parity Hypotheses, Exchange Rates Policy and Price for Solomon Islands}

\subsection{PPP Hypothesis}

Understanding PPP theory is the cornerstone of the monetary models of exchange rate determination (Dornbusch, 1976; Anoruo et al., 2005; Mussa, 1982) which attracts a lot of research in the vast literature. 
After the collapse of Bretton Wood system in 1971, many countries' currencies became free floating and are exposed to exchange rate shocks. The PPP theory thus came into play. The law states that under the assumption of the absence of transportation costs and trade barriers, or low transport costs the price of a good in two countries should be equal if they are of the same quality and are expressed in terms of the same currency (Jayaraman \& Choong, 2014). This is often referred to as the law of one price.

Cassel's (1920) view of the PPP is that the exchange rate S is relative price of two currencies. Since the purchasing power of the home currency is $1 / P$ and the purchasing power of the foreign currency is $1 / P^{*}$, in equilibrium the relative value of two currencies should reflect their relative purchasing powers, is $S=P / P^{*}$. Further, the Casselian view suggests using the general price level proxies such as the Consumer Price Index (CPI), in the empirical implementation of the theory. The theory implies that the $\log$ real exchange rate, $q=s+p^{*}-p$ is constant over time. However international macroeconomists view Casselian PPP only as a theory of long run determination of exchange rates (Nelson, 2001).

The commodity arbitrage view of PPP, articulated by Samuelson (1964), simply says that the "law of one price" holds for all internationally tradable goods. Thus the appropriate price index to study PPP may be the Producer Price index, or Wholesale Price Index, since it may be weighted towards tradable goods than the CPI which includes items such as housing services, which do not trade internationally.

The PPP theory stipulates that the exchange rate adjusts overtime to accommodate inflation differentials between the two countries (Anoruo et al., 2005). The theory was tested by carrying out the hypothesis for short and long-run adjustments of the exchange rate and price differential. If no restriction was set on the coefficient of the domestic and foreign price and non-cointegration was rejected then a weak version of PPP is favored. To obtain a strong PPP, a "restriction" was imposed by assigning unity (1) and minus unity (-1) to the coefficient of the domestic and foreign prices respectively and use the log likelihood test to determine the symmetry of the price differential (Jayaraman \& Choong, 2014; Paul \& Motlaleng, 2008, 2006).

Testing PPP hypothesis is important because firstly due to its theoretical perspective in monetary economics which assumes that there is a long-run relationship between money, price and exchange rate (Frenkel \& Johnson, 1978). Secondly the practical perspective of foreign exchange risk management by various economic agent in taking the long-run or short-run on foreign exchange related assets. Taking a long-run view is sometimes advised (Paul \& Motlaleng, 2008, 2006).

When float exchange rate began the relative prices between two countries are expected to reflect the changes in the nominal exchange rates. But as (Paul \& Motlaleng, 2008) note in their literature there was a substantial deviation of the exchange rates observed during this period, not only of the nominal exchange rates but more importantly of the real exchange rates. Furthermore, the high correlation between the nominal and real exchange rates has raised suspicions that nominal exchange rate do not revert back to its stable equilibrium mean values.

The turning point for the PPP investigation began when (Meese \& Singleton, 1982) found that the nominal exchange rate have a unit root. This means that nominal exchange rate follows a random walk, 
indicating that its impact is not mean-reverting. In other words, changes in the nominal exchange rates are expected to be permanent and as result fail to confirm the long-run PPP theory. Thereafter many researchers were unable to reject the hypothesis of a unit root for real exchange rates, and of non-cointegration of nominal exchange rates and relative prices.

But, this has changed in the 1990's after many new studies published by the following authors (Rogoff, 1996; Lothian, 1997; Lothian \& Taylor, 1996) has shown evidence of mean reversion and confirms the long-run PPP theory. Most authors agree that deviation from PPP frequently occurs in a short-run (Dornbusch, 1976; Frenkel, 1978). Dornbusch (1976) suggests that this deviation is due to different speed of adjustment in the asset market on one hand and prices of goods market on the other hand. However, all study focus on validity of PPP on the long-run has produced mixed results (Anoruo et al., 2005). For example (Jayaraman \& Choong, 2014; Paul \& Motlaleng, 2008, 2006; Abuaf \& Jorion, 1990; Meese \& Rogoff, 1988) have evidence to support the PPP in a long-run, while (Cooper, 1994; Ahking, 1997) obtained evidence against it.

Paul and Motlaleng (2006) in their literature note the validity of the long-run PPP theory using annual data of sixteen African countries from period covering 1981 to 1994 . The aforesaid authors further noted twenty African countries using multilateral trade weighted exchange rate indices and panel unit root techniques and concluded that the PPP theory is valid for those countries. While Jayaraman and Choong (2014) use annual data from the period 1981 to 2011 to determine the validity of long-run PPP theory for five PICs.

On the contrary (Cooper, 1994) investigated the validity of PPP by testing unit root and cointegration for Australian, New Zealand and Singaporean currencies from 1973-1992 and found that both tests fail to satisfy long-run PPP. Later (Ahking, 1997) employ a more advanced Bayesian unit root approach and found that there is little probability that exchange rate and price level have a steady relationship in a longrun.

There are different tests in the vast literature to determine the validity of PPP theory. For example Manzur and Ariff (1995) and Whitt (1992) used Sim tests; Ahking (1997) used Bayesian unit root approach. Huang and Yang (1996) employed the Engle and Granger (1987) two-step approach and Johansen (1988) used a maximum likelihood procedure as well as Monte-Carlo simulations and obtained different results. While Lee (1999) used a generalized error correction model for thirteen Asian countries.

To determine the validity of PPP in a long-run, Paul and Motlaleng (2008), Jayaraman and Choong (2014) uses different econometric techniques such as panel unit root tests, as well as Pedroni's and Johansen's panel co-integration tests. Their results were based on the panel context of rejecting the null hypothesis of non-cointegration. The study has shown evidence that real exchange rates revert to long-run equilibrium. To test the validity of a strong PPP hypothesis by panel analysis, the requirement is to have the existence of the two restrictive conditions relating to joint symmetry and proportionality. That is to set the coefficient of domestic price to unity (1) and on foreign price as of minus unity (-1). Khan and Parikh (1998) used the Johansen-Juselius approach in a bivariate context and reject the rand/pound and accept 
rand/dollar exchange rate. While Jayaraman and Choong (2014), Paul and Motlaleng (2008) uses Johansen multivariate approach the former reject the exchange per five PICs while the latter accepts the Pula/dollar exchange rate for Botswana. The results indicate that domestic and foreign prices determine the exchange rate in the long run, but mixed in the restrictive condition.

Many studies regarding PPP theory were done in developed and developing countries but less in PICs. The result of these study shows that PPP theory deviates in a short-run but mixed for long run and restrictive condition. PICs should continue to be guided by the PPP theory, to enable them to apply the appropriate measures which regards to price level and the exchange rate policy.

\subsection{Nominal-Exchange-Regime Neutrality}

A broad and important class of theoretical models of exchange-rate determination embodies the property of nominal-exchange-regime neutrality. This property is that the behavior of real exchange rate between two countries should not be significantly and systematically affected by the nature of regime controlling the nominal exchange rate between two countries. In particular, the behavior of real exchange rates under a floating-exchange regime should not be significantly and systematically different from behavior under fixed or adjust-able-peg exchange regimes. However, instantaneous adjustments in asset and commodity market price levels may be only possible in pure theoretical models, and short term deviations from the PPP may be frequently occurring in the floating exchange rate regimes. But, on the other side, some people believe that no such PPP theory can work in a peg exchange rate regime such as in our country sample of the study, Solomon Islands because exchange rates are controlled by the authorities, and such belief may be due to the lack of proper understanding of the theory of the PPP, and the monetary theories of price determination in an open economy, and the implication of the hypothesis of the nominal-exchange-regime neutrality. In such a backdrop, a study of the PPP theory, along with the price determination for the small open economy of the Solomon Islands countries, will be interesting.

\subsection{Exchange Rate Policy of Solomon Islands}

Solomon Islands Dollar (SBD) followed a fixed exchange rate regime until 2012 when the "de facto" peg to US dollar was changed to an invoiced-based basket of currencies (Jayaraman \& Choong, 2014). The basket of currencies consists of US dollar, Australian dollar, Japanese Yen and British pound (CBSI, 2005).

The weights assigned to each currency reflect its importance in trade with Solomon Islands with US dollar having the largest proportion. The Central Bank of Solomon Islands (CBSI) administers and manages the exchange rate of Solomon Islands. SBD was devalued once during this sample period by 20\% in 1997 and revalued by 5\% in June 2011. The literature discussed in this section is based from 1999 to 2013 CBSI annual report as the information from before 1998 was not available online.

During the ethnic conflict on Guadalcanal from 1998 to 2003, SBD was temporally pegged to USA dollar a move aimed at controlling inflationary pressure and to sustain import cover as a result of low export volume. This was due to the closer of two major industries located on Guadalcanal, gold ridge mining and palm oil industry which contributes significantly to country's total export volume (CBSI, 2000). The 
temporally pegging to USD was later removed and SBD was allowed to fluctuate with other traded currencies. The bank in 2006 adjusted downwards SBD by $25 \%$ what could be a fifth devaluation in an interval of about ten years since its establishment. A measure taken in order to sustain growth and reduce inflation as result of local dollar sharp depreciation (CBSI, 2007) which was supported by IMF and the World Bank. However, it was later revoked by the then minister of finance minister due to lack of government support.

The current fixed exchange regime monetary policy generally meant to provide an avenue for exchange control and avoid exogenous shocks to the bank. But this does not mean SBD is immune from external shocks coming from basket of currencies in which it was pegged to such as US dollar. For instance, an increase in the price oil would affect US dollar and the shock will then transmit to Solomon Islands dollar. This becomes evident during the global economic recession in 2008 which has forced the exchange rate of the local dollar to decline by $3 \%$ from $\$ 7.75 /$ USD to $\$ 8.00 /$ USD due to its pegging to USA dollar. In 2006, SBD was maintained under manage crawling pegging regime (Note 1), with the value derived from basket of foreign currencies (CBSI, 2006). CBSI and the national government have agreed to maintain the peg with the emphasis of stabilizing SBD against USD. The Government revalued SBD by 5\% in June 2011 (CBSI, 2011) in a move to arrest inflationary pressure in the economy. This resulted in the appreciation of 15\% Real Effective Exchange Rate (REER) against the traded basket of currencies. The real effective appreciation has forced the export to be less competitive and import on the other hand to become more competitive which then helped eased the inflationary pressure during the year. Another direct impact of this appreciation is the consequent reduction of Solomon Islands foreign debts and income.

In October 2012, the bank (CBSI, 2012) has changed the exchange rate regime from the "de facto" peg to USD to an invoiced-based basket of currencies. This change will allow more flexibility and management of the exchange rate to be more in line with economic fundamentals. Under this regime SBD is allowed to fluctuate within the narrow band of $\pm 1 \%$ with respect to a base currency and then to the components of the basket of currencies.

\subsection{Inflation in Solomon Islands}

Inflation in Solomon Islands is relatively high compared to its major trading partners and rated as one of the highest in the developing PICs (CBSI, 2001). For instance, the highest average annual inflation rate during this period was recorded at 15.4\% and 19.4\% in 2002 and 2008 respectively (CBSI, 2008, 2002). Despite the fall in the inflation rate of SBD major trading partners, the inflation rate known as the Honiara Retail Price index (HRPI) (Note 2) are still remain higher which reflects the high cost of doing business in Solomon Islands. This is a classic example of why nominal exchange rate changes may not pass through to domestic prices as found in the literature (Paul \& Motlaleng, 2008). After 2003, the inflation rate seems to be stable at around $6 \%$ this was due to the government policy of maintaining inflation rate at a single digit (CBSI, 2006) and pegging of Solomon dollar to US dollar. It was noted in this annual report that the oil prices were the main factor that drives other prices and contributes to the 
increase in inflation for imported items. The effect of a 5\% revaluation of the local currency on June 2011 has only helped to cushion the domestic prices against high global fuel prices but did not pass on the effect to the consumers. This effect was noted by (Paul \& Motlaleng, 2008, 2006) in Botswana's wholesale sector, where the lack of competition enabling importers to absorb the beneficial impact of currency appreciation in their profit margins, only passing the negative impact of depreciation to consumers. In 2012 the CBSI passed the price stability act (CBSI, 2012) which came into effect on January 2013. The act gave mandate to the CBSI board to develop a 5 years strategic change agenda for 2013-2017 with an aim of bring the Solomon Islands inflation on par with developing PICs.

\section{Methodology}

\subsection{Data and Variables}

The study has used the monthly average period observation from January 1993 to December 2014 for exchange rate and Consumer Price Index for United States and United Kingdom against Solomon Islands. The data seasonally unadjusted are obtained from IMF's international financial statistics. Exchange rates were given as number of Solomon dollars per US dollar and Solomon dollars per UK pound. The natural logarithm of US and UK exchange rates are subtracted from natural logarithm of Solomon Islands and are represented by $R^{U S}$ and $R^{U K}$ respectively. Similarly, the natural logarithm of US and UK Consumer Price Indexes are subtracted from the natural logarithm of Solomon Islands and are represented by $P^{U S}$ and $P^{U K}$ respectively. CPI is indexed to 2010 .

\subsection{Unit Root Test}

Unit-root analysis figure is very important in exchange rate studies. The presences of a unit root indicate that a time series is not stationary. To test the stationarity of a time series, we utilize the cointegration analysis. Since this study use multi-variate cointegration it is appropriate to employ the Augmented Dick-Fuller (ADF) (Dickey \& Fuller, 1979) test based on t-ratio of the parameter as given in equation (1).

$$
\Delta q_{t}=\beta_{0}+\beta_{1} t+\Pi_{i} q_{t-i}+\sum_{i=1}^{p} \quad \Gamma_{i} \Delta q_{t-i}+\epsilon_{t}
$$

Where $\mathrm{q}$ is the dependent variable in this case is the exchange rate $\Delta$ is the first difference operator, $\mathrm{t}$ is the time trend and $\epsilon$ is the random error and $\mathrm{p}$ is the maximum lag length. The optimal lag length is chosen so that lag length is $\epsilon_{t} \sim \mathrm{N}\left(0, \sigma_{\varepsilon_{t}}^{2}\right)$ is independent and identical distribution (i.i.d) with mean zero and constant standard deviation. While $\beta_{0}, \beta_{1}, \Pi$ and $\Gamma$ are parameters to be estimated. Under the null hypothesis, $\Delta q_{t}$ is in level form or I ( 0 ) which implies that $\Pi=0$ and then we conclude that the series under consideration has a unit root and is therefore non-stationary. To achieve stationarity further differencing is required so that $0<\Pi<1$ or is inside the unit circle.

\subsection{Akaike Information Criteria (AIC) and Schwarz Information Criteria (SIC)}

Determining optimal lag length is crucial in multiple linear regressions because they are sensitive to lag length (p). To maximize normal likelihood, we choose $\mathrm{p}$ to minimize $\hat{\rho}_{p}^{2}$ which is the estimated error covariance in sample $\mathrm{N}$ as given in equation (2).

$$
\hat{\rho}_{p}^{2}=S S E_{p} / N
$$


Where,

$N=$ sample size (Number of usable observation)

$p=$ Lag length

Akaike Information Criteria (AIC) (Akaike, 1974) is the most popular information criteria used to determine the value of $\mathrm{p}$. AIC modify the likelihood $\ln \left(\frac{S S E_{p}}{N}\right)$ by adding penalty on each additional lags as in equation (3).

$$
A I C_{p}=\ln \left(\hat{\rho}_{p}^{2}\right)+\frac{2 r}{N}
$$

Another model selection criterion is Schwarz Information Criteria (SIC) (Schwarz, 1978), it is an extension of Bayesian Information Criteria. SIC suggests that $\mathrm{p}$ values are too large by adding greater penalty on the parameters ( $r$ ) as given in equation (4) below.

$$
S I C_{p}=\ln \left(\hat{\rho}_{p}^{2}\right)+\frac{r \ln (N)}{N}
$$

Where,

$\mathrm{R}=\mathrm{p}+1$, number of parameters (regression coefficient) in the model.

The preferred model is one with the minimum value of AIC and SIC from their corresponding $i^{\text {th }}$ and $j^{\text {th }}$ candidate models. Let,

$$
\begin{aligned}
A I C_{i \text { min }} & =A I C_{1}, A I C_{2}, \ldots, A I C_{L} \\
S I C_{j \text { min }} & =S I C_{1}, S_{C} C_{2}, \ldots, S_{C} C_{K}
\end{aligned}
$$

$\mathrm{L}$ and $\mathrm{K}$ are length of candidate models, thus the optimal lag length $\mathrm{p}$ is obtained by evaluating equation (7).

$$
p=\min \left(A I C_{i \min }, S I C_{j \min }\right)
$$

ln $N>2$; for $N \geq 8$ : $\Rightarrow A I C>S I C$; from equation (3) and (4) which means that SIC will always select $h$ as the optimal lag length than AIC (Mukhtar \& Rasheed, 2010). The fit of the model improves as $\{$ AIC, SIC $\} \rightarrow-\infty$ [AIC and SIC can be both either negative or positive].

\subsection{Cointegration}

The unit root processes $\left\{q_{t}\right\}$ and $\left\{f_{t}\right\}$ will be cointegrated if there exist a linear combination of the two time series that is stationary. To understand the implications of cointegration, let's first look at what happens when the observations are not cointegrated.

\subsubsection{No Cointegration}

Let $\xi_{t}=\xi_{q t-1}+\mu_{q t}$ and $\xi_{t}=\xi_{f t-1}+\mu_{f t}$ be two independent random walk processes, where $\mu_{q t} \sim N\left(0, \sigma_{q}^{2}\right)$ and $\mu_{f t} \sim N\left(0, \sigma_{f}^{2}\right)$ and are independent and identical distribution (i.i.d). Let $z_{t}=$ $\left(z_{q t}, z_{f t}\right)^{\prime}$ follow a stationary bivariate process such as Vector Autoregressive (VAR). The next process for $\underline{z_{t}}$ does not need to be explicitly modeled at this point. Now consider the two unit root series built up from these components:

$$
\begin{aligned}
& q_{t}=\xi_{q t}+z_{q t} \\
& f_{t}=\xi_{f t}+z_{f t}
\end{aligned}
$$


Since $q_{t}$ and $f_{t}$ are driven by independent random walks, they will drift arbitrarily far apart from each other over time. If we try to find a value of $\beta$ to form a stationary linear combination of $q_{t} f_{t}$, we will fail, because,

$$
q_{t}-\beta f_{t}=\left(\xi_{q t}-\beta \xi_{f t}\right)+\left(z_{q t}-\beta z_{f t}\right)
$$

For any value of $\beta,\left(\xi_{q t}-\beta \xi_{f t}\right)=\left(\tilde{u}_{1}+\tilde{u}_{2}+\cdots+\tilde{u}_{t}\right)$, where $\tilde{u}_{t}=u_{q t}-\beta \mu_{f t}$ so the linear combination itself is random walk $\left\{q_{t}\right\}$ and $\left\{f_{t}\right\}$ clearly do not share a long-run relationship. There may, however, be short-run interactions between their first differences:

$$
\left(\Delta q_{t} \Delta f_{t}\right)=\left(\Delta z_{q t} \Delta z_{f t}\right)+\left(\epsilon_{q t} \epsilon_{f t}\right)
$$

If $\underline{z_{t}}$ follows a first-order VAR, we can show that equation (11) follows a vector ARMA process. Thus, when both $\left\{q_{t}\right\}$ and $\left\{f_{t}\right\}$ be first order differenced to induce stationarity and then their first differences modeled as a stationary vector process.

\subsubsection{Cointegration}

$\left\{q_{t}\right\}$ and $\left\{f_{t}\right\}$ will be cointegrated if they are driven by the same random walk, $\xi_{t}=\xi_{t-1}+\epsilon_{t}$ where $\epsilon_{t} \sim N\left(0, \sigma^{2}\right)$ and is i.i.d. For example,

$$
\begin{gathered}
q_{t}=\xi_{t}+z_{q t} \\
f_{t}=\varnothing\left(\xi_{t}+z_{f t}\right)
\end{gathered}
$$

And we look for a value of $\beta$ in equation (13) that renders stationary,

$$
q_{t}-\beta f_{t}=(1-\emptyset \beta) \xi_{t}+z_{q t}-\emptyset \beta z_{f t}
$$

we will succeed by choosing $\beta=\frac{1}{\emptyset}$, since $q_{t}-\frac{f_{t}}{\emptyset}=z_{q t}-z_{f t}$ is the difference between two stationary processes, so it will itself be stationary. $\left\{q_{t}\right\}$ and $\left\{f_{t}\right\}$ will share a long-run relationship. We say that they are cointergrated, with cointegrating vector $\left(1,-\frac{1}{\varnothing}\right)$. Since the random walks are sometimes referred to as stochastic trend processes, when two series are cointegrated we sometimes say they share a common trend.

\subsection{Vector Error-Correction Representation (VECM)}

For the univariate AR (2) process, we can write $q_{t}=\rho_{1} q_{t-1}+\rho_{2} q_{t-2}+\mu_{t}$ in Augmented Dick-Fuller test equation as,

$$
\Delta q_{t}=\left(\rho_{1}+\rho_{2}-1\right) q_{t-1}-\rho_{2} \Delta q_{t-1}+\mu_{t}
$$

Where $\mu_{t} \sim N\left(0, \sigma_{u}^{2}\right)$ and is i.i.d. If $q_{t}$ is a unit root process, then $\left(\rho_{1}+\rho_{2}-1\right)=0$ and $\left(\rho_{1}+\rho_{2}-\right.$ $1)^{-1}$ clearly does not exist. There is a sense a singularity in $q_{t-1}$, because $\Delta q_{t}$ is stationary and this can be true only if $q_{t-1}$ drops out from the right-hand side of equation (14).

By analogy, suppose that in bivariate case the vector $\left(q_{t}, f_{t}\right)$ is generated according to,

$$
\left[q_{t} f_{t}\right]=\left[\begin{array}{llll}
a_{11} & a_{12} & a_{21} & a_{22}
\end{array}\right]\left[\begin{array}{ll}
q_{t-1} f_{t-1}
\end{array}\right]+\left[\begin{array}{llll}
b_{11} & b_{12} & b_{21} & b_{22}
\end{array}\right]\left[q_{t-2} f_{t-2}\right]+\left[\mu_{q t} \mu_{f t}\right]
$$

Where $\left(\mu_{q t}, \mu_{f t}\right) \sim N\left(0, \Sigma_{u}\right)$ and is i.i.d. Rewrite equation (15) as a vector analog of the augmented Dick-Fuller test equation,

$$
\left[\Delta q_{t} \Delta f_{t}\right]=\left[r_{11} r_{12} r_{21} r_{22}\right]\left[q_{t-1} f_{t-1}\right]-\left[b_{11} b_{12} b_{21} b_{22}\right]\left[\Delta q_{t-1} \Delta f_{t-1}\right]+\left[\mu_{q t} \mu_{f t}\right]
$$


Where

$$
\left[r_{11} r_{12} r_{21} r_{22}\right]=\left[a_{11}+b_{11}-1 a_{12}+b_{12} a_{21}+b_{22} a_{22}+b_{22}-1\right] \equiv R
$$

If $\left\{q_{t}\right\}$ and $\left\{f_{t}\right\}$ have unit-root processes, their first difference are stationary. This means that the terms on the right hand side of equation (16) are stationary. Linear combinations of levels of the variables appear in the system $r_{11} q_{t-1}+r_{12} f_{t-1}$ appears in the equation for $\Delta q_{t}$ and $r_{21} q_{t-1+} r_{22} f_{t-1}$ appears in the equation for $\Delta f_{t}$.

If $\left\{q_{t}\right\}$ and $\left\{f_{t}\right\}$ do not cointegrate, there are no values of the $r_{i j}$ coefficients that can be found to form stationary linear combination of $\left\{q_{t}\right\}$ and $\left\{f_{t}\right\}$. The level terms must drop out. $\mathbf{R}$ is the null matrix, and $\left(\left\{q_{t}\right\},\left\{f_{t}\right\}\right)$ follows a vector autoregression.

If $\left\{q_{t}\right\}$ and $\left\{f_{t}\right\}$ do cointegrate, then there is a unique combination of the two variables that is stationary. The levels enter on the right-hand side, but do so in the same combination in both equations. This means that the column of $\mathbf{R}$, which is singular, and can written as

$$
R=\left[r_{11}-\beta r_{11} r_{21}-\beta r_{21}\right]
$$

Equation (11) can be written as

$$
\begin{aligned}
& {\left[\Delta q_{t} \Delta f_{t}\right]=\left[r_{11} r_{21}\right]\left(q_{t-1}-\beta f_{t-1}\right)-\left[b_{11} b_{12} b_{21} b_{22}\right]\left[\Delta q_{t-1} \Delta f_{t-1}\right]+\left[\mu_{q t} \mu_{f t}\right]=} \\
& {\left[r_{11} r_{21}\right] z_{t-1}-\left[b_{11} b_{12} b_{21} b_{22}\right]\left[\Delta q_{t-1} \Delta f_{t-1}\right]+\left[\mu_{q t} \mu_{f t}\right]}
\end{aligned}
$$

Where $z_{t-1} \equiv q_{t-1}-\beta f_{t-1}$ is called the error-correcting term, and equation (17) is the Vector Error-Correction Representation (VECM).

A VAR in first difference would be misspecified, because it omits the error-correction term. To express the dynamics governing $z_{t}$, multiply the equation by $\Delta f_{t}$ by $\beta$ and subtract the result from the equation for $\Delta q_{t}$, to give

$$
z_{t}=\left(1+r_{11}-\beta r_{21}\right) z_{t-1} q_{t-1}-\left(b_{11}-\beta b_{21}\right) \Delta q_{t-1}-\left(b_{12}+\beta b_{22}\right) \Delta f_{t-1}+\mu_{q t}-\beta \mu_{f t}
$$

The entire system is given by

$$
\begin{aligned}
& {\left[\Delta q_{t} \Delta f_{t} z_{t}\right]=} \\
& {\left[b_{11} b_{12} r_{11} b_{21} b_{22} r_{12}-\left(b_{11}+\beta b_{21}\right)-\left(b_{12}+\beta b_{22}\right) 1+r_{11}-\beta r_{21}\right]\left[\Delta q_{t-1} \Delta f_{t-1} z_{t-1}\right]+} \\
& {\left[\mu_{q t} \mu_{f t} \mu_{q t}-\beta \mu_{f t}\right]}
\end{aligned}
$$

$\left(\Delta q_{t}, \Delta f_{t}, z_{t}\right)^{\prime}$ is stationary vector, and (19) looks like a VAR (1) in these three variables, except that the columns of the coefficient matrix are linearly dependent. In many applications, the cointegration vector $(1,-\beta)$ is given a priori by economic theory and does not need to be estimated. In these situations, the linear dependence of the VAR in (19) tells us the information contained in the VECM is preserved in bivariate VAR form $z_{t}$ and either $\Delta q_{t}$, or $\Delta f_{t}$.

Suppose that we know this strategy. To obtain the VAR for $\left(\Delta q_{t}, \Delta f_{t}\right)$ substitute $f_{t-1}=\left(q_{t-1}-z_{t-1}\right) / \beta$ into the equation (14) for $\Delta q_{t}$, to get,

$$
\Delta q_{t}=b_{11} \Delta q_{t-1}+b_{12} \Delta f_{t-1}+r_{11} z_{t-1}+\mu_{q t}=a_{11} \Delta q_{t-1}+a_{12} z_{t-1}+a_{13} z_{t-2}+\mu_{q t}
$$

Where $a_{11}=b_{11}+b_{12} / \beta, a_{12}=r_{11}-b_{12} / \beta$, and $a_{13}=b_{12} / \beta$. Similarly, substitute $f_{t-1}$ out of the equation for $z_{t}$, to give,

$$
z_{t}=a_{21} \Delta q_{t-1}+a_{22} z_{t-1}+a_{23} z_{t-2}+\left(\mu_{q t}+\mu_{f t}\right)
$$


Where $a_{21}=-\left(b_{11}+\beta b_{21}+\frac{b_{12}}{\beta}+b_{22}\right), a_{22}=1+r_{11}-\beta r_{21}+b_{22}+\frac{b_{12}}{\beta}$, and $a_{23}=-\left(b_{22}+\frac{b_{12}}{\beta}\right)$.

Together, we have the VAR (2)

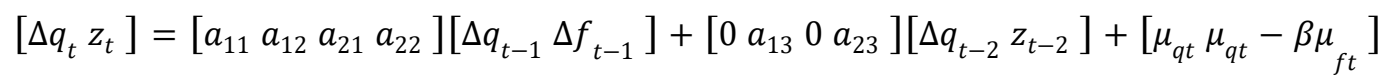

Equation (20) is easier to estimate than the VECM and the standard forecasting formulae for VARs can be employed without modification.

\subsection{Models for Exchange Rate, CPI}

In this section we present the empirical models and the variable description.

\section{Model 1}

$$
E\left(R_{t+1}\right)=\alpha+\beta S+U_{t} ; \beta>0
$$

Where $E\left(R_{t+1}\right)$ is the expected nominal exchange rate (defined as the log of the number of the Solomon Islands dollar per foreign currency). $\mathrm{R}=\log$ of the Solomon dollar per foreign currency, $\mathrm{S}=\log$ of Solomon Islands consumer price index $(\mathrm{P})$ minus $\log$ of the foreign consumer price index $\left(\mathrm{P}^{*}\right)$ and $U_{t}$ is the stochastic disturbance term and $\mathrm{t}$ is the time captured.

The forgoing models approximate to an approximation of relative version of the PPP theory even though the dependent variable is not exactly the changes in exchange rate.

\section{Model 2}

$$
R_{t}=\alpha+\beta_{1} P_{t}+\beta_{2} P_{t}^{*}+U_{t} ; \beta_{1}>0 ; \beta_{2}<0
$$

Variables are in natural logarithms.

Using restriction for absolute version $-\beta_{1}=\beta_{2}$ equation (17) becomes,

$$
R_{t}=\alpha+\beta\left(P_{t}-P_{t}^{*}\right)+U_{t}
$$

The empirical estimation of equation (23) amounts to the testing of the absolute version hypothesis of the PPP theory. The model 2 does not follow from model 1 and it is independent. The symmetry and the proportionality assumptions of the PPP theory can be rigorously examined equation (23).

Even though in strict PPP theory of the absolute version $\beta_{1}=1$ and $\beta_{2}=-1$, the orders of the magnitude can deviate slightly from unit coefficient and still maintain the proportionality and symmetry in strong version of the PPP theory.

\section{Results and Discussion}

The tables 1 and 2 shows result of ADF unit root tests for Solomon Islands exchange rate against USA and UK CPI. 
Table 1. ADF Unit Root Test for Solomon Islands against USA

\begin{tabular}{lllll}
\hline Variables & Level & $1^{\text {st }}$ difference & Decision & Integration \\
\hline Nominal exchange rate & -1.966534 & $-19.68182^{* * *}$ & Not stationary at level but stationary & $\mathrm{I}(1)$ \\
Ln(SOUS) & {$[0.3016]$} & {$[0.0000]$} & at $1^{\text {st }}$ difference & \\
& $(1)$ & $(0)$ & & \\
Domestic price, $\mathrm{P}^{\text {SOL }}$ & -1.808363 & $-14.32068^{* * *}$ & Not stationary at level but stationary & $\mathrm{I}(1)$ \\
Ln(SOCPI) & {$[0.3760]$} & {$[0.0000]$} & at $1^{\text {st }}$ difference & \\
& $(0)$ & $(0)$ & & \\
Foreign price, $\mathrm{P}^{\mathrm{US}}$ & -0.916386 & $-10.53842^{* * *}$ & Not stationary at level but stationary & $\mathrm{I}(1)$ \\
Ln(USCPI) & {$[0.7820]$} & {$[0.0000]$} & at $1^{\text {st }}$ difference & \\
& $(2)$ & $(1)$ & & \\
Price differential $\left(\mathrm{P}^{\mathrm{SOL}}-\mathrm{P}^{\mathrm{US}}\right)$ & -1.584530 & $-14.92235^{* * *}$ & Not stationary at level but stationary & $\mathrm{I}(1)$ \\
DLn(SOUSCPI) & {$[0.4890]$} & {$[0.0000]$} & at $1^{\text {st }}$ difference & \\
& $(0)$ & $(0)$ & & \\
\hline
\end{tabular}

Note. Null hypothesis: unit root (assume common root process). Asterisks ${ }^{* * *}$ and ${ }^{* *}$ show significant at $1 \%$ and $5 \%$ level respectively. The p-values are estimated from one-sided standardized normal distribution. The common lag length is chosen based on SIC and is in bracket ( ). Mackinnon probability (1999) is on parenthesis [ ].

Price differential is not stationary at level but stationary at first difference and is highly significant at $1 \%$ level. Also other variables are not stationary at level but stationary at first difference and are highly significant.

Table 2. ADF Unit Root Test for Solomon Islands against UK

\begin{tabular}{lllll}
\hline Variables & Level & $1^{\text {st }}$ difference & Decision & Integration \\
\hline Nominal exchange rate & -1.716327 & $-16.45216^{* * *}$ & Not stationary at level but stationary at & $\mathrm{I}(1)$ \\
Ln(SOUK) & {$[0.4218]$} & {$[0.0000]$} & $1^{\text {st }}$ difference & \\
& $(0)$ & $(0)$ & & \\
Domestic price, $\mathrm{P}^{\mathrm{SOL}}$ & -1.808363 & $-14.32068^{* * *}$ & Not stationary at level but stationary at & $\mathrm{I}(1)$ \\
Ln(SOCPI) & {$[0.3760]$} & {$[0.0000]$} & $1^{\text {st }}$ difference & \\
& $(0)$ & $(0)$ & & \\
Foreign price, $\mathrm{P}^{\mathrm{UK}}$ & 1.519202 & -2.327963 & Not stationary at level and not & \\
Ln(UKCPI) & {$[0.9993]$} & {$[0.1640]$} & stationary at $1^{\text {st }}$ difference & $\mathrm{I}(? ?)$ \\
& $(14)$ & $(11)$ & & \\
Price differential $\left(\mathrm{P}^{\mathrm{SOL}}-\mathrm{P}^{\mathrm{UK}}\right)$ & -2.039921 & -15.94570 & Not stationary at level but stationary at & $\mathrm{I}(1)$ \\
DLn(SOUKCPI) & {$[0.2697]$} & {$[0.0000]$} & $1^{\text {st }}$ difference & \\
& $(0)$ & $(0)$ & & \\
\end{tabular}


Note. Null hypothesis: unit root (assume common root process). Asterisk ${ }^{* * *}$ and ${ }^{* *}$ indicate significant at $1 \%$ and 5\% level respectively. The p-values are estimated from one-sided standardized normal distribution. The common lag length is chosen based on SIC and is in bracket ( ). Mackinnon probability (1999) is on parenthesis [ ].

Price differential is not stationary at level but stationary at first difference and is highly significant at $1 \%$ level. It is interested to note that CPI for UK is not stationary for both level and first difference format but stationary at their difference. While other variables are not stationary at level but stationary at first difference and are highly significant.

The tables 3 and 4 show results of unrestricted Johansen cointegration tests for Solomon Islands, USA and UK nominal exchange rate and CPIs.

Table 3. Johansen Multi-Variate Cointegration Test Result for Solomon Islands and USA CPI

\begin{tabular}{llllll}
\hline $\begin{array}{l}\text { Null } \\
\text { hypothesis }\end{array}$ & $\begin{array}{l}\text { Alternative } \\
\text { hypothesis }\end{array}$ & Eigen-values & $\begin{array}{l}\text { Maximum Eigen } \\
\text { statistics } \lambda_{\text {max }}\end{array}$ & 0.05 Critical values & Probabilities \\
\hline$r=0$ & $r \geq 1$ & 0.170534 & $46.18230^{* * *}$ & 22.29962 & 0.00000 \\
$r \leq 1$ & $r \geq 2$ & 0.049189 & 12.45867 & 15.89210 & 0.1609 \\
$r \leq 2$ & $r \geq 3$ & 0.011454 & 2.845581 & 9.164546 & 0.6100 \\
& & & Trace statistics $\lambda_{\text {trace }}$ & & \\
$r=0$ & $r=1$ & 0.170534 & $61.48655^{* * *}$ & 35.19275 & 0.00000 \\
$r \leq 1$ & $r=2$ & 0.049189 & 15.30425 & 20.26184 & 0.2094 \\
$r \leq 2$ & $r=3$ & 0.011454 & 2.845581 & 9.164546 & 0.6100 \\
\hline
\end{tabular}

Note. No deterministic trend (restricted constant). Variables included, LNSOCPI, LNUSCPI and LNESOUS: $\mathrm{N}=247,1993$ M06 to 2013 M12. Asterisk ${ }^{* * *}$ and ${ }^{* *}$ rejection of null hypothesis at $1 \%$ and $5 \%$ level of significant respectively. ${ }^{*}$ Probabilities are calculated using MacKinnon-Haug-Michelis (1999) p-values.

Normalized cointegrating coefficient (standard error in bracket):

$$
\begin{aligned}
\text { LNESOUS }= & 65.38677+6.949295 * \text { LNSOCPI }-20.80586 * \text { LNUSCPI } \\
& (21.3992)
\end{aligned}
$$

Table 3 shows that there is 1 cointegrating equation that is significant at $5 \%$ level of confidence. There exist 1 cointegrating equation between Solomon Islands and USA CPI. Both Maximum-Eigen and Trace statistic indicates 1 cointegration equation and are significant at MacKinnon probability of less than $1 \%$. The equation shows the negative sign correctly. All variable are in logarithm and may interpret the coefficient in terms of elasticity. The depreciation of the local dollar will cause an increase in the 
domestic price and a decrease in the foreign prices. In numerical terms, a $1 \%$ increase in the nominal exchange rate is associated with a decrease of $21 \%$ of USA prices and an increase of $7 \%$ of Solomon Islands prices. This follows the PPP theory.

Table 4. Johansen Multi-Variate Cointegration Test Result for Solomon Islands and UK, Nominal Exchange Rate and CPIs

\begin{tabular}{|c|c|c|c|c|c|}
\hline $\begin{array}{l}\text { Null } \\
\text { hypothesis }\end{array}$ & $\begin{array}{l}\text { Alternative } \\
\text { hypothesis }\end{array}$ & Eigen-values & $\begin{array}{l}\text { Maximum Eigen } \\
\text { statistics } \lambda_{\max }\end{array}$ & 0.05 Critical value & Probabilities \\
\hline$r=0$ & $r \geq 1$ & 0.199679 & $55.01730^{* * *}$ & 22.29962 & 0.00000 \\
\hline$r \leq 1$ & $r \geq 2$ & 0.069618 & $17.82351^{* *}$ & 15.89210 & 0.0246 \\
\hline \multirow[t]{2}{*}{$r \leq 2$} & $r \geq 3$ & 0.033953 & 8.532195 & 9.164546 & 0.0658 \\
\hline & & & Trace statistics $\lambda_{\text {trace }}$ & & \\
\hline$r=0$ & $r=1$ & 0.199679 & $81.37300^{* * *}$ & 35.19275 & 0.00000 \\
\hline$r \leq 1$ & $r=2$ & 0.069618 & $26.35570^{* * * *}$ & 20.26184 & 0.0063 \\
\hline$r \leq 2$ & $r=3$ & 0.033953 & 8.532195 & 9.164546 & 0.0658 \\
\hline
\end{tabular}

Note. No deterministic trend (restricted constant). Variables included, LNSOCPI, LNUKCPI and LNESOUK. $\mathrm{N}=247,1993$ M06 to 2013 M12. Asterisk ${ }^{* * *}$ and ${ }^{* * *}$ rejection of null hypothesis by $5 \%$ and $1 \%$ respectively. ${ }^{*}$ Probabilities are calculated using MacKinnon-Haug-Michelis (1999) p-values.

Normalized cointegrating coefficients (standard error in bracket):

LNESOUK $=25.70709+2.29792 *$ LNSOCPI $-7.61245 *$ LNUKCPI
(2.15402)
$(0.16203)$
$(0.54085)$

Table 4 shows that there are 2 cointegrating equations that is significant at $5 \%$ level of confidence. Interestingly there exist 2 cointegrating equations between Solomon Islands and UK prices. Both Maximum-Eigen and Trace statistic indicates 2 cointegration equations and are significant at Mackinnon probabilities of $1 \%$ and $5 \%$ respectively. We will only consider 1 cointegrating equation since the value of Maximum-Eigen statistic is not significant at $1 \%$ level of confidence for the 2 cointegrating equation. The equation shows the negative sign correctly. All variable are in logarithm and may interpret the coefficient in terms of elasticity. The depreciation of the local dollar will cause an increase in the domestic price and a decrease in the foreign prices. In numerical terms, a $1 \%$ increase in the nominal exchange rate is associated with a decrease of $7.6 \%$ of UK prices and an increase of $2.3 \%$ of Solomon Islands prices. This again follows the PPP theory. 
Table 5. Normalized Cointegrating Vectors for Solomon Islands and USA Prices

\begin{tabular}{ll}
\hline Cointegrating equation & Cointegrating vectors 1 \\
\hline LNSOCPI (-1) & 1.000000 \\
LNUSCPI (-1) & -2.0963478 \\
& $(0.13700)$ \\
& {$[-21.6318]$} \\
LNESOUS (-1) & -0.155083 \\
& $(0.06004)$ \\
& {$[-2.58292]$} \\
C & 9.313120 \\
& $(0.51617)$ \\
& {$[18.0426]$} \\
\hline
\end{tabular}

Note. Standard error is in brackets ( ) and t-statistic is in parenthesis [ ].

Table 5 we normalized cointegrating vectors for Solomon Islands Price. This indicates that an increase in local price is caused by the decrease in the value of local dollar and a decrease in the USA prices. This follows PPP theory. The cointegrating vector in Table 5 is employed to derive the VECM model for LNESOUS.

Table 6. Vector Error Correcting Estimate (VECM) for Variables LNESOUS, LNSOCPI and LNUSCPI for Solomon Islands and US Prices

\begin{tabular}{llll}
\hline Error Correction & $\mathrm{D}($ LNSOCPI $)$ & $\mathrm{D}($ LNUSCPI $)$ & $\mathrm{D}$ (LNESOUS) \\
\hline $\mathrm{D}($ LNSOCPI (-1)) & 0.089107 & 0.034541 & 0.181969 \\
& $(0.06292)$ & $(0.01731)$ & $(0.14874)$ \\
& {$[1.28509]$} & {$[1.99591]$} & {$[1.22337]$} \\
$\mathrm{D}($ LNSOCPI (-2)) & -0.016050 & 0.055473 & 0.010917 \\
& $(0.06191)$ & $(0.01736)$ & $(0.14920)$ \\
& {$[-0.25926]$} & {$[3.19556]$} & {$[0.07317]$} \\
D(LNUSCPI (-1)) & 0.320230 & 0.547877 & -0.817417 \\
& $(0.22367)$ & $(0.06272)$ & $(0.53907)$ \\
& {$[1.43173]$} & {$[8.73537]$} & {$[-1.51634]$} \\
D(LNUSCPI (-2)) & -0.525259 & -0.292236 & -0.466542 \\
& $(0.22367)$ & $(0.06416)$ & $(0.55148)$ \\
D(LNESOUS (-1)) & {$[-2.29559]$} & {$[-4.55462]$} & {$[-0.84599]$} \\
& -0.012094 & -0.002220 & -0.280968 \\
\hline
\end{tabular}




\begin{tabular}{llll}
\hline & {$[-0.44987]$} & {$[-0.29445]$} & {$[-4.33647]$} \\
D(LNESOUS $(-2))$ & -0.043191 & -0.011071 & -0.145976 \\
& $(0.02676)$ & $(0.00750)$ & $(0.06448)$ \\
VECM coefficients & {$[-1.61432]$} & {$[-1.47557]$} & {$[-2.26374]$} \\
& -0.075950 & -0.007509 & -0.062681 \\
& $(0.00926)$ & $(0.00260)$ & $(0.02232)$ \\
& {$[-8.20106]^{* * *}$} & {$[-2.89152]^{* * *}$} & {$[-2.80824]^{* * *}$} \\
\hline
\end{tabular}

Note. Standard error is in brackets ( ) and t-statistic is in parenthesis [ ]. Asterisk ${ }^{* *}$ and ${ }^{* * *}$ indicates significance at $5 \%$ and $1 \%$ respectively.

In VECM coefficients in Table 6, when DLNESOUS is taken as dependent variable, VECM have the correct negative sign and is statistical significant at $1 \%$ level. This means that the change in nominal exchange rate is caused by the trend in change in prices of US and Solomon Islands prices. It is very interesting to note that, it will take at least $6 \%$ of disequilibrium to be corrected and will take a very long time to be corrected. However, if DLNSOCPI is taken as dependent variable, VECM has the correct sign and is significant. This implies that Solomon Islands price is influenced by USA prices and the nominal exchange rate. In Table 10 when DLNUSCPI is taken as dependent variable VECM is negative and significant at $1 \%$ level. This implies that the USA price is caused by nominal exchange rate and Solomon Islands prices. This is contrary to the normal expectations.

Table 7. Normalized Cointegrating Vectors for Solomon Islands and UK Prices

\begin{tabular}{ll}
\hline Cointegrating equation & Cointegrating equation 1 \\
\hline LNSOCPI (-1) & 1.000000 \\
LNUKCPI (-1) & -2.750389 \\
& $(0.30470)$ \\
& {$[-9.02660]$} \\
LNESOUK (-1) & -0.459985 \\
& $(0.09493)$ \\
& {$[-4.84576]$} \\
C & 9.002663 \\
& $(1.20703)$ \\
\end{tabular}

Note. Standard error is in brackets ( ) and t-statistic is in parenthesis [ ].

Table 7 we normalized cointegrating vectors for Solomon Islands Price. The signs are opposite sign and indicate that an increase in local price is caused by the decrease in the value of local dollar and a decrease 
in the UK price. This follows PPP theory. The cointegrating vector in Table 7 is employed to derive the VECM model for LNESOUK.

Table 8. Vector Error Correcting Estimate (VECM) for Variables LNESOUK, LNSOCPI and LN UKCPI for Solomon Islands and UK Prices

\begin{tabular}{|c|c|c|c|}
\hline Error Correction & D(LNSOCPI) & D(LNUKCPI) & D(LNESOUK) \\
\hline \multirow[t]{4}{*}{ D(LNSOCPI (-1)) } & 0.094942 & 0.071696 & 0.111095 \\
\hline & $(0.06337)$ & $(0.02154)$ & $(0.19227)$ \\
\hline & [1.49833] & [3.32784] & {$[0.57780]$} \\
\hline & -0.060878 & 0.019709 & -0.472517 \\
\hline \multirow[t]{2}{*}{ D(LNSOCPI (-2)) } & $(0.06412)$ & $(0.02180)$ & $(0.19455)$ \\
\hline & {$[-0.94948]$} & [0.90409] & {$[-2.42872]$} \\
\hline \multirow[t]{3}{*}{ D(LNUKCPI(-1)) } & 0.375401 & -0.042232 & 0.622767 \\
\hline & $(0.19196)$ & $(0.06527)$ & $(0.58248)$ \\
\hline & [1.95560] & {$[-0.64706]$} & [1.06917] \\
\hline \multirow[t]{3}{*}{ D(LNUKCPI(-2)) } & -0.076758 & -0.085265 & -0.814240 \\
\hline & $(0.18857)$ & $(0.06411)$ & $(0.57219)$ \\
\hline & {$[-0.40705]$} & {$[-1.32987]$} & {$[-1.42303]$} \\
\hline \multirow[t]{3}{*}{ D(LNESOUK(-1)) } & -0.002998 & -0.010434 & -0.045808 \\
\hline & $(0.02114)$ & $(0.00719)$ & $(0.06415)$ \\
\hline & {$[-0.14183]$} & {$[-1.45156]$} & {$[-0.71410]$} \\
\hline \multirow[t]{3}{*}{ D(LNESOUK(-2)) } & -0.023920 & 0.000178 & -0.031480 \\
\hline & $(0.02111)$ & $(0.00718)$ & $(0.06406)$ \\
\hline & {$[-1.13303]$} & {$[-0.02476]$} & {$[-0.49142]$} \\
\hline \multirow[t]{3}{*}{ VECM coefficients } & -0.023889 & -0.004714 & -0.025075 \\
\hline & $(0.00362)$ & $(0.00123)$ & (0.01099) \\
\hline & {$[-6.59523]^{* * *}$} & {$[-3.82747]^{* *}$} & {$[-2.28147]^{* * *}$} \\
\hline
\end{tabular}

Note. Standard error is in brackets ( ) and t-statistic is in parenthesis [ ]. Asterisk ${ }^{* *}$ and ${ }^{* * *}$ indicates significance at $5 \%$ and $1 \%$ respectively.

In VECM coefficients in Table 8, when DLNESOUK is taken as dependent variable, VECM have the correct negative sign and is statistical significant. This means that the change in nominal exchange rate is caused by the trend in changes in UK price and Solomon Islands price. It will take at least $2 \%$ of disequilibrium to be corrected and this will take a long time to be corrected. However, when DLNSOCPI is taken as dependent variable, VECM has the correct sign and is significant. This implies that Solomon Islands price is influenced by UK prices and the nominal exchange rate. In Table 8 when DLNUKCPI is 
taken as dependent variable and it is again interesting to note that VECM is negative and significant at $1 \%$ level. This means that the UK price is caused by the nominal exchange rate and the local price. This is again not consistent with normal belief.

\section{Testing the absolute version-Symmetry and Proportionality—of PPP}

The tables 9 and 10 show results of the Johansen cointegration test result for Solomon Islands and USA nominal exchange rate and CPIs.

Table 9. Johansen Multi-Variate Unrestricted Cointegration Test Result for Solomon Islands and USA CPI

\begin{tabular}{|c|c|c|c|c|c|}
\hline $\begin{array}{l}\text { Null } \\
\text { hypothesis }\end{array}$ & $\begin{array}{l}\text { Alternative } \\
\text { hypothesis }\end{array}$ & Eigen-values & $\begin{array}{l}\text { Maximum Eigen } \\
\text { statistics } \lambda_{\max }\end{array}$ & 0.05 Critical Value & Probabilities \\
\hline$r=0$ & $r \geq 1$ & 0.231984 & $65.72218^{* * *}$ & 22.29962 & 0.00000 \\
\hline$r \leq 1$ & $r \geq 2$ & 0.044395 & 11.30734 & 15.89210 & 0.2299 \\
\hline \multirow[t]{2}{*}{$r \leq 2$} & $r \geq 3$ & 0.011751 & 2.943349 & 9.164546 & 0.5913 \\
\hline & & & Trace statistics $\lambda_{\text {trace }}$ & & \\
\hline$r=0$ & $r=1$ & 0.231984 & $79.97287^{* * *}$ & 35.19275 & 0.00000 \\
\hline$r \leq 1$ & $r=2$ & 0.044395 & 14.25069 & 20.26184 & 0.2725 \\
\hline$r \leq 2$ & $r=3$ & 0.011751 & 2.943349 & 19.164546 & 0.5913 \\
\hline
\end{tabular}

Note. No deterministic trend (restricted constant). Variables included LNSOCPI, LNUSCPI and LNESOUS: $\mathrm{N}=247,1993$ M04 to 2013 M12. Asterisk ${ }^{* * *}$ and ${ }^{* *}$ rejection of null hypothesis at $1 \%$ and $5 \%$ level of significant respectively. * Probabilities are calculated using MacKinnon-Haug-Michelis (1999) p-values.

Table 9 shows that there is 1 cointegrating equation that is significant at $5 \%$ level of confidence. There exist 1 cointegrating equation between Solomon Islands and USA CPI. Both Maximum-Eigen and Trace statistic indicates 1 cointegration equation and are significant at MacKinnon probability of less than $1 \%$. Table 10 shows results when applying likelihood ratio test to examine the joint symmetry and proportionality restriction. Here we set the coefficient of LNSOCPI $=1$, LNUSCPI $=-1$ and LNESOUS $=-1$ as the restriction condition.

Table 10. Johansen Multi-Variate Restricted Cointegration Test for Solomon Islands and United States: LR-Test

\begin{tabular}{lllll}
\hline Hypothesized No. of CE(s) & Restricted Log-Likelihood & LR statistic & Degrees of freedom & Probability \\
\hline$R=1$ & 2445.165 & 12.99208 & 2 & 0.001509 \\
$R=2$ & 2454.818 & $*$ & $*$ & $*$ \\
\hline
\end{tabular}

Note. * convergences not achieved. 
LR statistic indicates that there is a strong version of PPP for Solomon Islands against USA at $1 \%$ significant level.

The tables 11 and 12 show results of Johansen cointegration test result for Solomon Islands and UK nominal exchange rate and CPIs.

Table 11. Johansen Multi-Variate Unrestricted Cointegration Test Result for Solomon Islands and UK, Nominal Exchange Rate and CPIs

\begin{tabular}{|c|c|c|c|c|c|}
\hline $\begin{array}{l}\text { Null } \\
\text { hypothesis }\end{array}$ & $\begin{array}{l}\text { Alternative } \\
\text { hypothesis }\end{array}$ & Eigen-values & $\begin{array}{l}\text { Maximum Eigen } \\
\text { statistics } \lambda_{\max }\end{array}$ & 0.05 Critical Value & Probabilities \\
\hline$r=0$ & $r \geq 1$ & 0.215469 & $60.42475^{* * *}$ & 22.29962 & 0.00000 \\
\hline$r \leq 1$ & $r \geq 2$ & 0.060698 & 15.59190 & 15.89210 & 0.0557 \\
\hline \multirow[t]{2}{*}{$r \leq 2$} & $r \geq 3$ & 0.021081 & 5.305234 & 9.164546 & 0.2516 \\
\hline & & & Trace statistics $\lambda_{\text {trace }}$ & & \\
\hline$r=0$ & $r=1$ & 0.215469 & $81.32189^{* * *}$ & 35.19275 & 0.0000 \\
\hline$r \leq 1$ & $r=2$ & 0.060698 & $20.89714^{*}$ & 20.26184 & 0.0409 \\
\hline$r \leq 2$ & $r=3$ & 0.021081 & 5.305234 & 9.164546 & 0.2516 \\
\hline
\end{tabular}

Note. No deterministic trend (restricted constant). Variables included, LNSOCPI, LNUKCPI and LNESOUK. $\mathrm{N}=247,1993$ M04 to 2013 M12. Asterisk ${ }^{* *}$ and ${ }^{* * *}$ rejection of null hypothesis by $5 \%$ and $1 \%$ respectively. * Probabilities are calculated using MacKinnon-Haug-Michelis (1999) p-values.

Table 11 shows that there are 1 cointegrating equations that is significant at $1 \%$ level of confidence. Maximum-Eigen statistics indicates 1 cointegrating equation at $1 \%$ significance while trace statistics indicates 2 cointegration equations and are significant at Mackinnon probabilities of 1\% and 5\% respectively. We follow the Eigen-maximum statistic and accept 1 cointegrating equations between Solomon Islands and UK prices.

Table 12 shows results when applying likelihood ratio test to examine the joint symmetry and proportionality restriction. Here we set the coefficient of LNSOCPI = 1, LNUKCPI = -1 and LNESOUK $=-1$ as the restriction condition.

Table 12. Johansen Multi- Variate Restricted Cointegration Test for Solomon Islands and United Kingdom: LR-Test

\begin{tabular}{lllll}
\hline Hypothesized No. of CE(s) & Restricted Log-Likelihood & LR statistic & Degrees of freedom & Probability \\
\hline$R=1$ & 2327.528 & 2.911207 & 2 & 0.233260 \\
$R=2$ & 2337.035 & $*$ & $*$ & $*$ \\
\hline
\end{tabular}

Note. * convergences not achieved. 
LR statistic indicates that a strong version of PPP for Solomon Islands against UK is not significant. Solomon Islands share a weak PPP relationship with the United Kingdom.

We imposed the cointegration restriction as LNSOCPI $(-1)=1$; LNUKCPI $(-1)=-1 ; \operatorname{LNESOUS~}(-1)=-1$. No deterministic trend (restricted constant). LR test for binding restrictions $($ Rank $=1)$; Chi-square $(2)=$ 12.99208; Probability $=0.001509$.

Table 13. Normalized Cointegration Equation after Imposing Restriction Placed on the Coefficient of LNSOCPI (-1), D(LNUSCPI (-1)) and D(LNESOUS (-1))

\begin{tabular}{ll}
\hline Cointegrating equation & Cointegrating equation 1 \\
\hline LNSOCPI (-1) & 1.000000 \\
LNUSCPI (-1) & -1.000000 \\
LNESOUS (-1) & -1.000000 \\
C & 1.538565 \\
& $(0.08525)$ \\
& {$[18.0471]$} \\
\hline
\end{tabular}

Note. $\mathrm{N}=249,1993$ M04 to 2013 M12.

The Chi-square statistics show that the null hypothesis that the symmetry and proportionality hypothesis is valid for the Solomon Islands country is rejected for the Solomon-USA exchange rate. This is consistent with the earlier finding of Jayaraman et al.

Next we are testing the symmetry and proportionality test for the Solomon Islands-UK pound exchange rate. We imposed the cointegration restriction as LNSOCPI $(-1)=1$; LNUKCPI $(-1)=-1$; LNESOUK $(-1)$ $=-1$. No deterministic trend (restricted constant). LR test for binding restrictions (Rank $=1$ ); Chi-square $(2)=2.911207 ;$ Probability $=0.2332603$.

The Chi-square statistics results show that the null hypothesis that the restrictions are valid is not rejected at the conventional levels of even up to 10 per cent. This implies that for the Solomon Islands-UK exchange rate symmetry and proportionality hypothesis of the PPP is valid.

Table 14. Normalized Cointegration Equation after Imposing Restriction Placed on the Coefficient of LNSOCPI (-1), LNUKCPI (-1) and LNESOUK (-1)

\begin{tabular}{ll}
\hline Cointegrating equation & Cointegrating equation 1 \\
\hline LNSOCPI(-1) & 1.000000 \\
LNUKCPI(-1) & -1.000000 \\
LNESOUK(-1) & -1.000000 \\
& 0.934685 \\
C & $(0.22068)$ \\
& {$[4.23548]$} \\
\hline
\end{tabular}

Note. $\mathrm{N}=249,1993$ M04 to 2013 M12. 
As given in Table 14, the restrictions for absolute version of the PPP theory are not supported by the Chi-square statistics. This implies the exchange rate of Solomon Islands with respect to the UK is not very appropriate for the application of the PPP theory.

To see the VECM of the restricted version we set the coefficient of LNSOCPI, LNOUKCPI and LNESOUK to $(1,-1,-1)$ respectively as shown in Table 15 .

Table 15. Vector Error Correcting Estimate (VECM) for Variables LNSOCPI, LNUKCPI and LESOUK for Solomon Islands and US Prices

\begin{tabular}{llll}
\hline Error Correction & D(LNSOCPI) & D(LNUKCPI) & D(LNESOUK) \\
\hline D(LNSOCPI (-1)) & 0.101394 & 0.066408 & 0.104683 \\
& $(0.06470)$ & $(0.02150)$ & $(0.19348)$ \\
D(LNSOCPI (-2)) & {$[1.56716]$} & {$[3.08874]$} & {$[0.54105]$} \\
& -0.05344 & 0.014887 & -0.47735 \\
D(LNUKCPI (-1)) & $(0.06536)$ & $(0.02172)$ & $(0.19546)$ \\
& {$[-0.81761]$} & {$[0.68543]$} & {$[-2.44217]$} \\
& 0.435048 & -0.0468 & 0.652549 \\
D(LNUKCPI (-2)) & $(0.19353)$ & $(0.06431)$ & $(0.57875)$ \\
& {$[2.24794]$} & {$[-0.72773]$} & {$[1.12751]$} \\
D(LNESOUK (-1)) & -0.02694 & -0.09244 & -0.79611 \\
& $(0.19061)$ & $(0.06334)$ & $(0.57001)$ \\
& {$[-0.14136]$} & {$[-1.45936]$} & {$[-1.39666]$} \\
V(LNESOUK (-2)) & 0.004096 & -0.00932 & -0.03893 \\
& $(0.02138)$ & $(0.00711)$ & $(0.06394)$ \\
& {$[0.19157]$} & {$[-1.31128]$} & {$[-0.60885]$} \\
& -0.01749 & 0.000705 & -0.02551 \\
& $(0.02135)$ & $(0.00709)$ & $(0.06384)$ \\
& {$[-0.81912]$} & {$[0.09936]$} & {$[-0.39948]$} \\
& -0.003477 & -0.000846 & -0.003971 \\
& $(0.00059)$ & $(0.00019)$ & $(0.00175)$ \\
& {$[-5.93560]^{* * *}$} & {$[-4.34706]^{* * *}$} & {$[-2.26704]^{* *}$} \\
\hline
\end{tabular}

Note. Standard error is in brackets ( ) and t-statistic is in parenthesis [ ]. Asterisk ${ }^{* *}$ and ${ }^{* * *}$ indicates $5 \%$ and $1 \%$ significant level respectively. $\chi_{2}^{2}=2.911207, p=0.233260$.

In VECM coefficients in Table 15, when DLNESOUS is taken as dependent variable, VECM have the correct negative sign and statistical significant at 5\% level. This means that the change in nominal exchange rate is caused by the trend in change in prices between UK and Solomon Islands which 
confirms the PPP theory. It will take less than $1 \%$ of disequilibrium to be corrected and this will take a very long time. Furthermore, if DLNSOCPI is taken as dependent variable, VECM has the correct sign and significant at $1 \%$ level. This implies that there is a causal relationship between Solomon Islands price to the nominal exchange rate and UK prices. In Table 15 when DLNUKCPI is taken as dependent variable that VECM is negative and significant at $1 \%$ level. This implies there is a causal relation between UK price to Nominal exchange rate and Solomon price. This is contrary to the fact that UK price is not caused by Solomon Islands. Interestingly, the coefficients of all the variables are significant, and are causing each other However, the UK price might be more influenced by its exchange rates as the Pound sterling depreciates in value the UK inflation increases corroborating the PPP theory as the UK is an open economy.

\section{Conclusion}

After carrying out the research we have found that there is a long-run relationship between Solomon Islands nominal exchange rates and the price differential against USA and UK prices. The weak form of the PPP theory is supported for the Solomon Islands countries against both the US dollar, and the UK pound Sterling. The strong form of the PPP theory - the symmetry and proportionality hypothesis - is supported for the Solomon against the UK currency only and not against USA Dollars. It is also noted that it will take a very long time before the disequilibrium to be corrected for both USA and UK prices as the value of $\alpha$ is less than $1 \%$. This finding confirms the result obtained by Jayaraman and Choong for Solomon Islands against USA using symmetry and proportional Log likelihood test. Using the VECM we have found that Solomon Islands price and nominal exchange rate is caused by changes in USA prices and UK prices.

\section{References}

Abuaf, N., \& Jorion, P. (1990). Purchasing Power Parity in the Long Run. The Journal of finance, 45, 157-174. https://doi.org/10.1111/j.1540-6261.1990.tb05085.x

Ahking, F. (1997). Testing long-run purchasing power parity with a Bayesian unit root approach: The experience of Canada in the 1950s. Applied Economics Letters, 29. https://doi.org/10.1080/000368497326732

Akaike, H. (1974). A new look at the statistical model identification. Automatic control, IEEE transactions on, 19, 716-723. https://doi.org/10.1109/TAC.1974.1100705

Anoruo, E., Braha, H., \& Ahmad, Y. (2005). Purchasing Power Parity: Evidence from developing Countries. International Advances in Economic Research, 82, 85-96.

CBSI. (2000). CBSI Annual Report 2000. Honiara: Central Bank of Solomon Islands.

CBSI. (2001). CBSI Annual Report 2001. Honiara: Central Bank of Solomon Islands.

CBSI. (2002). CBSI Annual Report 2002. Honiara: Central bank of Solomon Islands.

CBSI. (2005). CBSI quartely review, June 2005. Honiara: Central Bank of Solomon islands.

Published by SCHOLINK INC. 
CBSI. (2006). CBSI Annual Report 2006. Honiara: Central Bank of Solomon Islands.

CBSI. (2007). CBSI Annual Report 2007. Honiara: Central bank of solomon Islands.

CBSI. (2008). CBSI Annual report 2008. Honiara: Central Bank of Solomon Islands.

CBSI. (2011). CBSI Annual report 2011. Honiara: Central bank of Solomon Islands.

CBSI. (2012). CBSI Annual report 2012. Honiara: Central Bank of Solomon Islands.

Cooper, J. C. B. (1994). Purchasing power parity: A cointegration analysis of the Australian, New Zealand and Singaporean currencies. Applied Economics Letters, 1, 167-171. https://doi.org/10.1080/135048594357934

Dickey, D. A., \& Fuller, W. A. (1979). Distribution of the Estimators for Autoregressive Time Series With a Unit Root. Journal of the American Statistical Association, 74, 427-431.

Dornbusch, R. (1976). Expectations and exchange rate dynamics. Journal of Political Economy, 84, 1161-1176. https://doi.org/10.1086/260506

Frenkel, J. A., \& Johnson, H. G. (1978). The Economics of Exchange Rates, Reading, Mass. Addison Wesley.

Frenkel, J. A. (1978). Purchasing power parity: Doctrinal perspective and evidence from the 1920s. Journal of International Economics, 8, 169-191. https://doi.org/10.1016/0022-1996(78)90021-1

Huang, B.-N., \& Yang, C. W. (1996). Long-run purchasing power parity revisited: A Monte Carlo simulation. Applied Economics, 28, 967-974. https://doi.org/10.1080/000368496328092

Jayaraman, T. K., \& Choong, C.-K. (2014). Purchasing power parity theory and its validity in pacific islands countries. Bank of Valletta Review, 48, 41-52.

Johansen, S. (1988). Statistical Analysis of Co-integration Vectors. Journal of Economic Dynamics and Control, 12, 231-254. https://doi.org/10.1016/0165-1889(88)90041-3

Khan, B., \& Parikh, A. (1998). Does the purchasing power parity survive political shocks in South Africa? Weltwirtschaftliches Archiv, 134, 99-116. https://doi.org/10.1007/BF02707580

Lee, D. (1999). Purchasing power parity and dynamic error correction evidence from Asia Pacific economies. International Review of Economics and Finance, 8, 199-212. https://doi.org/10.1016/S1059-0560(99)00015-5

Lothian, J. R. (1997). Multi-country evidence on the behavior of purchasing power parity under the current float. Journal International Money and Finance, 16, 19-35. https://doi.org/10.1016/S0261-5606(96)00047-2

Lothian, J. R., \& Taylor, M. P. (1996). Real exchange rate behavior: The recent float from the perspective of the past two centuries. Journal of Political Economy, 104, 488-509. https://doi.org/10.1086/262031

Manzur, M., \& Ariff, M. (1995). Purchasing Power Parity: New Methods and Extensions. Applied Financial Economics, 5, 19-26. https://doi.org/10.1080/758527667

Meese, R. A., \& Singleton, K. J. (1982). On unit roots and the empirical modeling of exchange rates. The journal of finance, 37, 1029-1035. https://doi.org/10.1111/j.1540-6261.1982.tb03595.x 
Meese, R., \& Rogoff, K. (1988). Was It Real? The Exchange Rate-Interest Differential Relation over the Modern Floating-Rate Period. The Journal of Finance, 43, 933-948. https://doi.org/10.1111/j.1540-6261.1988.tb02613.x

Mukhtar, T., \& Rasheed, S. (2010). Testing the long run relationship between exports and imports: Evidence from Pakistan. Journal of Economic Cooperation and Development, 31, 41-58.

Mussa, M. (1982). A model of exchange rate dynamics. Journal of Political Economy, 90, 74-104. https://doi.org/10.1086/261040

Nelson, C. M. (2001). International Macroeconomics and Finance-Theory and Econometric Methric Methods. Blackwell Publishing.

Paul, T. M., \& Motlaleng, G. R. (2006). Money Demand and Purchasing Power Parity (PPP), in the Republic of South Africa. Journal Of Quantitative Economics, Journal of the Indian Econometric Society, 4, 1-27.

Paul, T. M., \& Motlaleng, G. R. (2008). The Pula-Dollar Exchange Rate and the Purchasing Power Parity in Botswana. Journal Of Developing Areas, 41. https://doi.org/10.1353/jda.2008.0001

Rogoff, K. (1996). The purchasing power parity puzzle. Journal of Economic Literature, 34, 647-668.

Schwarz, G. (1978). Estimating the dimension of a model. The Annals of Statistics, 6, 461-464. https://doi.org/10.1214/aos/1176344136

Whitt, J. A. J. (1992). The Long-Run Behavior of the Real Exchange Rate: A Reconsideration. Journal of Money, Credit and Banking, 24, 72-82. https://doi.org/10.2307/1992792

\section{Notes}

Note 1. Exchange rate mechanism which call for frequent redefining of the par value by small amounts to remove a payment disequilibrium.

Note 2. Honiara retail Price Index is often used as the consumer price index for Solomon Islands. 